
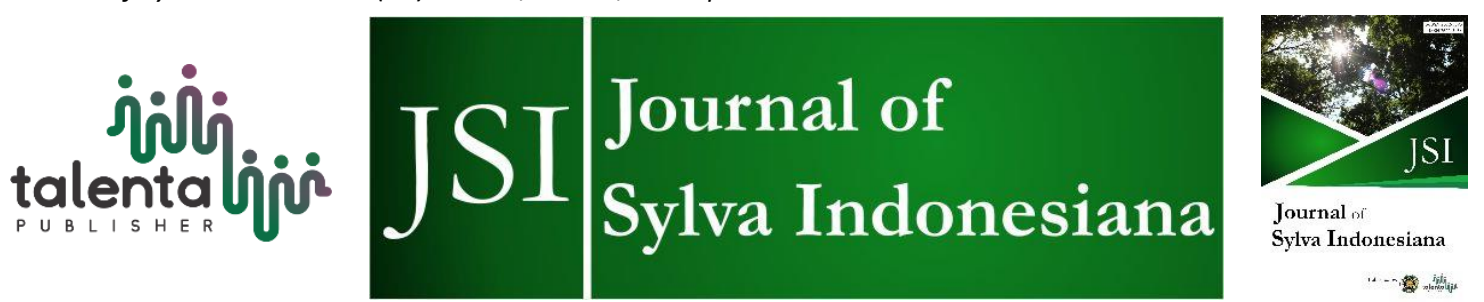

\title{
Mangrove Utilization as Sources of Ruminant Feed in Belawan Secanang Subdistrict, Medan Belawan District
}

\author{
Fahriza Zuhri', Delvian Delvian ${ }^{2 *}$, and Ma'ruf Tafsin ${ }^{3}$ \\ ${ }^{1}$ Master Program in Natural Resources and Environmental Management, School of Graduate Studies, \\ Universitas Sumatera Utara, Medan, North Sumatra 20155, Indonesia \\ ${ }^{2}$ Department of Forestry, Faculty of Forestry, Universitas Sumatera Utara, Medan, North Sumatra \\ 20155, Indonesia \\ ${ }^{3}$ Department of Animal Sciences, Faculty of Agriculture, Universitas Sumatera Utara, Medan, North \\ Sumatra 20155, Indonesia
}

\begin{abstract}
Mangroves hold several benefits, one of which is barriers from marine abrasion, food sources, aquatic habitats, carbon sinks and storages, places for education and training, ecotourism sites, and sources of ruminant feed. This study aimed to determine the potential of mangroves as sources of ruminant feed and its carrying capacity for sustainable mangrove utilization. The research was conducted in Belawan Sicanang Subdistrict by using purposive sampling for vegetation analysis and questionnaire method. Avicennia marina, Bruguiera sexangula, B. gymnorrhiza, Nypa fruticans, Rhizophora apiculata, Sonneratia alba, and Thespesia populnea were among the mangrove species used by the farmer. The total capacity of mangrove species as ruminant feed in the animal unit (AU) was obtained as dry matter (835.48 AU), crude protein (481.24 AU), and total digestible nutrient (873.77 AU). The carrying capacity of mangroves as represented in the form of dry matter (13.74), crude protein (7.91), and total digestible nutrient (14.36), were categorized as safe. In addition, the potential additional populations based on the safe level of carrying capacity (2.5) was $273 \mathrm{AU}$, based on crude protein for $131 \mathrm{AU}$, and based on total digestible nutrients for $288 \mathrm{AU}$.
\end{abstract}

Keyword: Animal Unit, Carrying Capacity, Mangrove, North Sumatra, Ruminant Feed

Received 29 April 2021 | Revised 29 June 2021 | Accepted 1 July 2021

\section{Introduction}

Mangroves provide a variety of benefits, including protection from marine abrasion, food sources, aquatic habitats, carbon sinks and storages, educational and training opportunities, ecotourism destinations, and ruminant feed [1]. Mangrove ecosystems serve a variety of functions, including physical, ecological, and socioeconomic. Physically, mangroves can

\footnotetext{
*Corresponding author at: Department of Forestry, Faculty of Forestry, Universitas Sumatera Utara, Medan, North Sumatra 20155, Indonesia

E-mail address: delvian@usu.ac.id

Published by Talenta Publisher

ISSN: 2622-5093 e-ISSN: 2622-5158 DOI : 10.32734/jsi.v5i01.6186

Journal Homepage: http://jsi.usu.ac.id
} 
tolerate tidal waves, storms, and tides at any time, thereby reducing coastal abrasion. Ecologically, mangroves have a function as a source of germplasm, spawning grounds, and nesting sites for marine organisms. Mangroves are also considered highly productive ecosystems because they serve as nutrient cycle reservoirs and a source of carbon and nitrogen for aquatic species. From a socioeconomic aspect, mangroves can be utilized as intercropping areas by protecting economically valuable brackish fish species, also known as silvofishery, and as tourism destinations [2]. Feed is an important element of the livestock industry; in fact, feed management is crucial to the success of any livestock business. The leaves of the api-api (Avicennia spp.) are used as animal feed by the local community in coastal areas of Indonesia. A study on the analysis of Avicennia marina leaves revealed the nutritional content of vitamin B (2.64 mg/100 g), vitamin C (15.32 mg/100 g), fiber (8.7\%), and carbohydrates (13\%) with high mineral contents promoting its utilization as a source of forage in animal feed [3]. The abundant mangroves in Belawan Sicanang Subdistrict could be studied being used by the local community as a potential source of ruminant feed. The research was carried out to determine mangrove species that could be used as a source of ruminant feed and the carrying capacity of mangroves in the area.

\section{Research Method}

\subsection{Field Sampling}

The research was conducted in Belawan Sicanang Subdistrict from October to December 2020. Belawan Sicanang Subdistrict is one of the six subdistricts located within Medan Belawan District, Medan City that develops into fishery sites, trading services, settlements, and others. The subdistrict holds an area of 1,786.91 ha with a mangrove area of 895.242 ha $(50.1 \%)$. Sampling sites for vegetation analysis used purposive sampling by placing plots $(5 \times 5 \mathrm{~m})$ to determine the mangrove species in the area for a total of 20 observation plots by considering the density of vegetation and geographical location (Figure 1). The observation sites were determined purposively by considering the geographical conditions and vegetation density that represent the actual biodiversity in the area. The additional method was employed by questionnaire to collect information from 22 goat breeders, 4 sheep breeders, 1 cattle breeder, and 1 buffalo breeder. The measuring tools consisted of GPS (Geographics Position System) to measure geographical coordinates, measuring tape to determine the area of observation plots, ropes to mark the observation plots, calipers to measure the tree diameters, field guide, and identification books to identify mangrove species and questionnaires to collect information from farmers using a list of questions previously prepared. The type of data obtained in this study was presented in Table 1. 


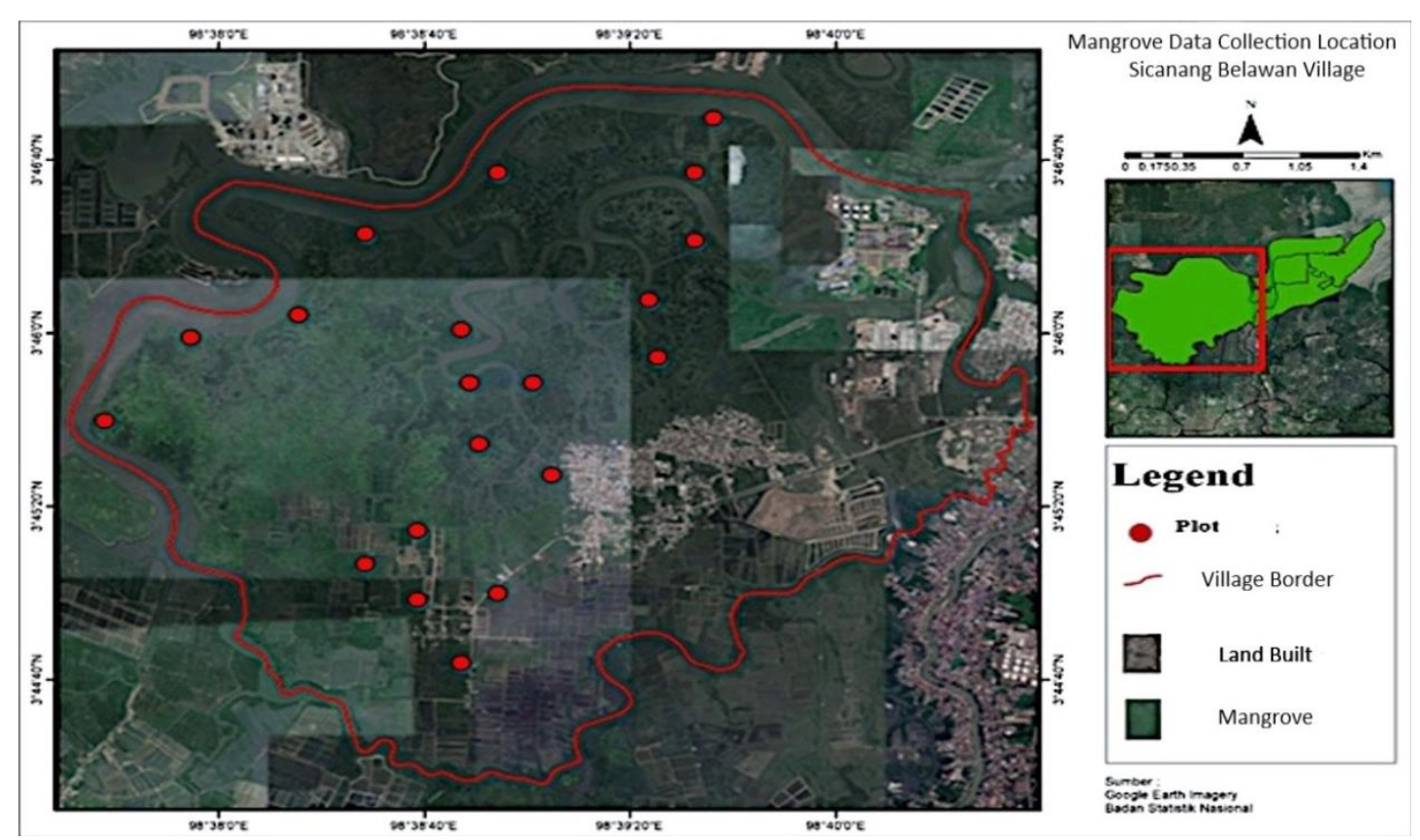

Figure 1 Map of study area in Belawan Sicanang Subdistrict

Table 1 Type of data, sources, and data collection techniques

\begin{tabular}{|c|c|c|}
\hline Type of Data & Source & Data Collection Technique \\
\hline $\begin{array}{ll}\text { a. } & \text { Primary } \\
- & \text { Mangrove forest (Plant } \\
& \text { species, potential of } \\
& \text { mangrove leaves as } \\
& \text { ruminant feed } \\
- & \text { Ruminant farm (Animal } \\
& \text { feed requisite, } \\
& \text { Information of utilized } \\
& \text { mangrove species) }\end{array}$ & $\begin{array}{l}\text { Study area in Belawan } \\
\text { Sicanang Subdistrict (in } \\
\text { situ) }\end{array}$ & $\begin{array}{l}\text { Direct field observation } \\
\text { and questionnaire-based } \\
\text { interviews }\end{array}$ \\
\hline $\begin{array}{ll}\text { b. } & \text { Secondary } \\
\text { - } & \text { Mangrove forest } \\
\text { - Number of Farmers } \\
\text { - } & \text { Number of Livestocks }\end{array}$ & $\begin{array}{l}\text { Related officials such as } \\
\text { administrative official } \\
\text { of the subdistrict, } \\
\text { Central Bureau of } \\
\text { Statistics in Medan }\end{array}$ & Literature study \\
\hline
\end{tabular}

\subsection{Data Analysis}

Data analysis in this study based on the ecological parameters of vegetation analysis which included [4]:

a. Density $(\mathrm{D})=$ Number of individuals of a species/ Area of observation

b. Relative density $(\mathrm{RD})=($ Density of a species/ Density of total species $) \times 100 \%$

c. Frequency $(F)=$ Number of times a species present/ Total number of observation plots

d. Relative frequency $(\mathrm{RF})=($ Frequency of a species/ Frequency of all species $) \times 100 \%$ 
e. Importance Value Index (IVI) $=\mathrm{RD}+\mathrm{RF}$

f. Shannon's diversity index $\left(\mathrm{H}^{\prime}\right)=-\sum_{i=1}^{s} p i \ln p i$

Where, $\mathrm{p}$ is the proportion of $(\mathrm{n} / \mathrm{N})$ of individuals of a certain plant species $(\mathrm{n})$ divided by the total number of individuals $(\mathrm{N})$. $\ln$ is a natural logarithmic value, $\Sigma$ is the sum of calculations while $s$ is the number of species. The level of species diversity is classified as high $\left(\mathrm{H}^{\prime}>3\right)$, moderate $\left(1 \leq \mathrm{H}^{\prime} \leq 3\right)$, and low $\left(\mathrm{H}^{\prime}<1\right)[5]$.

\subsection{Determination of Carrying Capacity}

Potency of mangrove species to be utilized as ruminant feed in Belawan Sicanang Subdistrict was converted into dry matter with desired water content $(<74 \%)$ dan volume in the field. The following formula was used in this study:

a. $\quad$ Forage production $=$ Numbe of forages $(\mathrm{kg}) \times$ Annual harvesting

b. Dry matter $=(100 \%-$ mean water content $) \times$ Forage production

c. Total dry matter production $=$ dry matter of a mangrove $($ ton/ha $) \times$ harvest area $($ ha $)$

d. Total crude protein $=$ Total dry matter production of a mangrove $\times$ crude protein

e. Total digestible nutrient (mangrove) $=$ Total dry matter production of a mangrove $\times$ total digestible nutrient of total species

f. Proximate content of each mangrove species for total digestibe nutrient (\%) [6] = 92.464 - 3.338 (Crude fibre) - 6.945 (Crude fat) - 0.726 (Non-nitrogen extract content/ $\mathrm{NNE})+1.115($ Crude protein $)+0.031(\text { Crude fibre })^{2}-0.133(\text { Crude fat })^{2}+0.036$ (Crude fibre) $(\mathrm{NNE})+0.207$ (Crude fat) $(\mathrm{NNE})+0,100$ (Crude fat) (Crude protein) 0.022 (Crude fat $^{2}$ (Crude protein)

The minimum feed requirement of ruminants for one livestock unit or animal unit (AU) is calculated with the assumption that $1 \mathrm{AU}$ of ruminants requires an average of $6.25 \mathrm{~kg}$ of dry matter/day or 2,282.25 kg/year [7], crude protein of $0.06 \mathrm{~kg} /$ day or $240.9 \mathrm{~kg} /$ year and total digestible nutrient of $4.3 \mathrm{~kg} /$ day or $1,569.5 \mathrm{~kg} /$ year [8]. The average nutrient content of mangrove leaves as a source of ruminant feed is presented in Table 2.

Table 2 Prediction of mean nutritional content of mangrove leaves as ruminant feed

\begin{tabular}{ccccccc}
\hline \multirow{2}{*}{ Material } & \multicolumn{6}{c}{ Nutrient (\%) } \\
\cline { 2 - 7 } & Carbohydrate & $\begin{array}{c}\text { Crude } \\
\text { Protein }\end{array}$ & $\begin{array}{c}\text { Crude } \\
\text { Fat }\end{array}$ & $\begin{array}{c}\text { Crude } \\
\text { Fibre }\end{array}$ & $\begin{array}{c}\text { Ash } \\
\text { Content }\end{array}$ & \multirow{2}{*}{ NNE } \\
\hline $\begin{array}{c}\text { Mangrove } \\
\text { leaves }\end{array}$ & 74 & 6.08 & 4.26 & 15.15 & 6.09 & 68.41 \\
\hline
\end{tabular}


In general, the requirement for forage (fresh) by ruminants is 10 percent of body weight. Nutrient requirements are fulfilled in an appropriate and balanced state if the capacity of feed consumed by the livestock can support their productivity [9]-[10]. The feed carrying capacity index $(\mathrm{CCI})$ is an index that indicates the standard criteria for the safety level of supply of forage [11]-[12]. The feed CCI was obtained from the multiplication of the number of livestock population (AU) and nutritional requirement ( $\mathrm{kg} / \mathrm{AU})$ divided by the total production $(\mathrm{kg})$. The criterion of an ideal condition based on feed CCI is presented in Table 3.

Table 3 Sustainability level of forage availability based on feed CCI

\begin{tabular}{lcc}
\hline No. & CCI & Category \\
\hline 1 & $>2$ & Safe (Sustainable) \\
2 & $1.5-2$ & Vulnerable \\
3 & $1-1.5$ & Critical \\
4 & $<1$ & Very critical \\
\hline
\end{tabular}

\section{Results and Discussion}

\subsection{Vegetation Analysis of Mangrove Species in Belawan Sicanang Subdistrict}

The study focused on the community structure formed by sapling species with girth characteristics are $<10 \mathrm{~cm}$ and height $>1.5 \mathrm{~m}$. The species composition and its ecological parameters are presented in Table 4.

Table 4 Vegetation analysis of mangrove species in Belawan Sicanang Subdistrict

\begin{tabular}{|c|c|c|c|c|c|c|c|c|}
\hline Species & $\sum_{\text {ind }}$ & $\sum_{\text {Plot }}$ & $\begin{array}{c}D \\
\text { (Ind/Ha) }\end{array}$ & $R D$ & $F$ & $R F$ & IVI & $H^{\prime}$ \\
\hline Aegiceras corniculatum (Teruntun) & 2 & 1 & 40 & 1.94 & 0.05 & 1.81 & 3.75 & \\
\hline Avicennia alba (Api-api Hitam) & 18 & 9 & 360 & 17.47 & 0.45 & 16.36 & 33.83 & \\
\hline Avicennia marina (Api-api putih) & 29 & 12 & 580 & 28.15 & 0.6 & 21.8 & 49.97 & \\
\hline Bruguiera cylindrical (Mata buaya) & 1 & 1 & 20 & 0.97 & 0.05 & 1.81 & 2.78 & \\
\hline $\begin{array}{l}\text { Bruguiera gymnnorrhiza } \\
\text { (Mata Buaya merah) }\end{array}$ & 4 & 2 & 80 & 3.88 & 0.1 & 3.63 & 7.51 & \\
\hline Bruguiera sexangula (Mata buaya) & 4 & 2 & 80 & 3.88 & 0.1 & 3.63 & 7.51 & \\
\hline Ceriops decandra (Tengal) & 1 & 1 & 20 & 0.97 & 0.05 & 1.81 & 2.78 & \\
\hline Ceriops tagal (Tengar) & 1 & 1 & 20 & 0.97 & 0.05 & 1.81 & 2.78 & \\
\hline Exocoecaria agallocha (Buta-buta) & 10 & 7 & 200 & 9.70 & 0.35 & 12.72 & 22.43 & 2.27 \\
\hline Lumnitzera racemosa (Truntum) & 1 & 1 & 20 & 0.97 & 0.05 & 1.81 & 2.78 & \\
\hline Nypa fruticans (Nipah) & 7 & 2 & 140 & 6.79 & 0.1 & 3.63 & 10.43 & \\
\hline Rhizophora apiculata (Bakau) & 10 & 4 & 200 & 9.70 & 0.2 & 7.27 & 16.98 & \\
\hline Rhizophora mucronata (Bakau kurap) & 2 & 2 & 40 & 1.94 & 0.1 & 3.63 & 5.57 & \\
\hline Sonneratia alba (Perepat) & 8 & 7 & 160 & 7.76 & 0.35 & 12.72 & 20.49 & \\
\hline Sonneratia caseolaris (Perepat merah) & 1 & 1 & 20 & 0.97 & 0.05 & 1.81 & 2.78 & \\
\hline Thespesia populnea (waru laut) & 2 & 1 & 40 & 1.94 & 0.05 & 1.81 & 3.75 & \\
\hline Xylocarpus granatum (Nyirih) & 2 & 1 & 40 & 1.94 & 0.05 & 1.81 & 3.75 & \\
\hline Total & 103 & & 2,060 & 100 & 2.75 & 100 & 200 & \\
\hline
\end{tabular}


Based on Table 4, the highest density and IVI was recorded from Avicennia marina (api-api) whereas Shannon's diversity index for the stage was 2.27 indicating a moderate level of diversity in the area. In a previous study, the documented mangrove species was only 8 species namely Sonneratia alba (Perepat), Sonneratia caseolaris (Perepat Merah), Rhizophora apiculata (Bakau), Rhizophora mucronata (Bakau Kurap), Avicennia alba (Api-api Hitam), Avicennia marina (Api-api putih), Bruguiera gymnnorrhiza (Mata Buaya merah), and Bruguiera hainessii (Berus Mata Buaya) with the diversity index ranged from 0.67 to 1.78 [13].

\subsection{Livestock Population in Belawan Sicanang Subdistrict}

Based on the survey of breeders namely 22 goat breeders, 4 sheep breeders, 1 cattle breeder, and 1 buffalo breeder, the livestock population in Belawan Sicanang Subdistrict is presented in Table 5 and Table 6.

Table 5 Livestock population of small ruminants in Belawan Sicanang Subdistrict

\begin{tabular}{|c|c|c|c|c|c|c|c|}
\hline & \multicolumn{6}{|c|}{ Age Structure } & \multirow{3}{*}{ Total } \\
\hline & \multicolumn{2}{|c|}{$\begin{array}{l}\text { Young } \\
(0-6 \text { mo })\end{array}$} & \multicolumn{2}{|c|}{$\begin{array}{l}\text { Adolescent } \\
(>6-13 \mathrm{mo})\end{array}$} & \multicolumn{2}{|c|}{$\begin{array}{c}\text { Adult } \\
(>13 \mathrm{mo})\end{array}$} & \\
\hline & Male & Female & Male & Female & Male & Female & \\
\hline Population & 13 & 37 & 31 & 88 & 41 & 149 & 359 \\
\hline Mean & 0.5 & 1.42 & 1.19 & 3.38 & 1.57 & 5.73 & 13.79 \\
\hline Animal Unit (AU) & \multicolumn{2}{|c|}{2} & \multicolumn{2}{|c|}{9.52} & \multicolumn{2}{|c|}{30.4} & 41.92 \\
\hline
\end{tabular}

Table 6 Livestock population of big ruminants in Belawan Sicanang Subdistrict

\begin{tabular}{|c|c|c|c|c|c|c|c|}
\hline & \multicolumn{6}{|c|}{ Age Structure } & \multirow{3}{*}{ Tota } \\
\hline & \multicolumn{2}{|c|}{$\begin{array}{c}\text { Young } \\
(0-6 \mathrm{mo})\end{array}$} & \multicolumn{2}{|c|}{$\begin{array}{l}\text { Adolescent } \\
(>6-13 \mathrm{mo})\end{array}$} & \multicolumn{2}{|c|}{$\begin{array}{c}\text { Adult } \\
(>13 \mathrm{mo})\end{array}$} & \\
\hline & Male & Female & Male & Female & Male & Female & \\
\hline Population & - & 2 & 3 & 6 & 3 & 10 & 24 \\
\hline Mean & - & 1 & 1,5 & 3 & 1,5 & 5 & 12 \\
\hline Animal Unit (AU) & \multicolumn{2}{|c|}{0.5} & \multicolumn{2}{|c|}{5.4} & \multicolumn{2}{|c|}{13} & 18.9 \\
\hline
\end{tabular}

\subsection{Mangrove Species Utilization as Ruminant Feed}

The livestock breeders in Belawan Sicanang Subdistrict commonly utilized mangrove leaves as goat feed from Avicennia marina (Api-api putih), Rhizophora apiculata (Bakau), Bruguiera sexangula (Mata buaya), Bruguiera gymnnorrhiza (Mata Buaya merah), Sonneratia alba (Perepat), Nypa fruticans (Nipah), and Thespesia populnea (waru laut). The frequency of mangrove species utilization by the breeders is presented in Table 7 . 
Table 7 Utilization frequency of mangrove by breeders in Belawan Sicanang Subdistrict

\begin{tabular}{lcc}
\hline \multirow{2}{*}{ Species } & \multicolumn{2}{c}{ Respondents $(N=26)$} \\
\cline { 2 - 3 } & $\sum$ & $\%$ \\
\hline Avicennia marina (Api-api putih) & Utilization frequency & \\
Bruguiera gymnnorrhiza (Mata Buaya merah) & 22 & 84.62 \\
Bruguiera sexangula (Mata buaya) & 5 & 19.23 \\
Nypa fruticans (Nipah) & 5 & 19.23 \\
Rhizophora apiculata (Bakau) & 8 & 30.77 \\
Sonneratia alba (Perepat) & 21 & 80.77 \\
Thespesia populnea (waru laut) & 12 & 46.16 \\
\hline
\end{tabular}

The frequently utilized mangrove species as ruminant feed for goats in Belawan Sicanang Subdistrict include young leaves or twigs $( \pm 50 \mathrm{~cm})$, which were obtained from the Avicennia marina (Api-api putih), Rhizophora apiculata (Bakau), and Sonneratia alba (Perepat). The leaves of A. marina were used to feed camels in the breeding areas around the Red Sea, India, and Australia. Meanwhile, in coastal areas of Indonesia, the local community utilized A. marina leaves to feed goats. The chemical composition contained in A. marina leaves such as vitamin B (2.64 mg/100 g), vitamin C (15.32 mg/100 g), crude fiber (8.7\%), carbohydrates (13\%), and high mineral content showed that the leaves have the potential as a source of forage for animal feed [3], [14].

\subsection{Mangrove Productivity as Ruminat Feed}

Based on the calculation and conversion of raw production and utilization of mangrove species in Belawan Sicanang Subdistrict, the mangrove productivity can be estimated (Table 8). The annual forage productivity may reach 8.19 ton/ha/year with the dry matter of 2.12 tons/ha/year with the mean utilization of 0.15 ton/ha/year and capacity of $0.93 \mathrm{AU} / \mathrm{ha} / \mathrm{year}$.

Table 8 Mangrove productivity as ruminant feed in Belawan Sicanang Subdistrict

\begin{tabular}{|c|c|c|c|c|c|}
\hline \multirow[b]{2}{*}{ Species } & \multirow{2}{*}{ Ind/Ha } & \multicolumn{2}{|c|}{$\begin{array}{l}\text { Productivity } \\
\text { (ha/year) }\end{array}$} & \multirow{2}{*}{$\begin{array}{l}\text { Mean } \\
\text { Utilizati } \\
\text { on }\end{array}$} & \multirow{2}{*}{$\begin{array}{c}\text { Dry matter } \\
\text { capacity } \\
\text { (AU/ha/ } \\
\text { year) }\end{array}$} \\
\hline & & $\begin{array}{l}\text { Forage } \\
\text { (Ton) }\end{array}$ & $\begin{array}{c}\text { Dry } \\
\text { matter } \\
\text { (year) }\end{array}$ & & \\
\hline Avicennia marina (Api-api putih) & 580 & 371 & 0.96 & & 0.42 \\
\hline $\begin{array}{l}\text { Bruguiera gymnnorrhiza } \\
\text { (Mata Buaya merah) }\end{array}$ & 80 & 0.51 & 0.13 & & 0.05 \\
\hline Bruguiera sexangula (Mata buaya) & 80 & 0.51 & 0.13 & & 0.05 \\
\hline Nypa fruticans (Nipah) & 140 & 0.89 & 0.23 & & 0.10 \\
\hline Rhizophora apiculata (Bakau) & 200 & 1.28 & 0.33 & & 0.14 \\
\hline Sonneratia alba (Perepat) & 160 & 1.02 & 0.26 & & 0.11 \\
\hline Thespesia populnea (Waru laut) & 40 & 0.25 & 0.06 & & 0.02 \\
\hline Total & 1,280 & 8.19 & 2.12 & 0.15 & 0.93 \\
\hline
\end{tabular}




\subsection{Mangrove Carrying Capacity as Ruminant Feed in Belawan Sicanang Subdistrict}

The mangrove carrying capacity as depicted from the feed CCI is presented in Table 9. Belawan Sicanang Subdistrict has a total production of dry matter of $1,906.79$ tons, crude protein of 115.93 tons, and total digestible nutrients (TDN) of 1,235.72 tons which can supply the dry matter need as much as 835.48 AU/year, crude protein of 481.28 AU/year and TDN of 873.77 AU/ha/year. The carrying capacity of mangroves as the ruminant source for dry matter, crude protein, and TDN were $13.74,7.91$, and 14.36 respectively which were categorized as safe or sustainable.

Table 9 Carrying capacity of mangrove (895.242 ha) in Belawan Sicanang Subdistrict

\begin{tabular}{cccccccccc}
\hline \multirow{2}{*}{ Source } & \multicolumn{3}{c}{ Production (ton) } & \multicolumn{3}{c}{ Capacity (AU/year) } & \multicolumn{3}{c}{ Carrying Capacity } \\
\cline { 2 - 10 } & DM & CP & TDN & DM & CP & TDN & DM & CP & TDN \\
\hline Mangrove & $1,906.79$ & 115.93 & $1,371.39$ & 835.48 & 481.24 & 873.77 & 13.74 & 7.91 & 14.36 \\
\hline
\end{tabular}

\subsection{Estimation of Additional Livestock Population in Belawan Sicanang Subdistrict}

Based on the sustainable level of carrying capacity $(\mathrm{CCI}=2.5)$ of mangrove in Belawan Sicanang Subdistrict, additional livestock population may still be adjusted with the dry matter, crude protein, and TDN of 273, 131, and 288 AU respectively.

\section{Conclussion}

Our study reported that the most utilized mangrove species by farmers were Avicennia marina, Bruguiera sexangula, B. gymnnorrhiza, Nypa fruticans, Rhizophora apiculata, Sonneratia alba, and Thespesia populnea. The total capacity of mangrove species as ruminant feed in the animal unit (AU) was obtained as dry matter (835.48 AU), crude protein (481.24 AU), and total digestible nutrient (873.77 AU). The carrying capacity of mangroves as represented in the form of dry matter (13.74), crude protein (7.91), and total digestible nutrient (14.36), were categorized as safe. In addition, the potential additional livestock populations based on the safe level of carrying capacity (2.5) was $273 \mathrm{AU}$, based on crude protein for $131 \mathrm{AU}$, and based on total digestible nutrients for $288 \mathrm{AU}$.

\section{REFERENCES}

[1] S. Rahim and D. Wahyuni (Ed.), Hutan Mangrove dan Pemanfaatannya, Deepublish, Yogyakarta, 2017.

[2] D. Sulastini, M. D. W. S. Mekar, U. Susilo, P. Oktadiyani, Seri Buku Informasi dan Potensi Mangrove Taman Nasional Alas Purwo, Balai Taman Nasional Alas Purwo, Banyuwangi, 2011.

[3] C. Kusmana, A. Suryani, Y. Hartati, P. Oktadiani, Pemanfaatan Jenis Pohon Mangrove Api-api (Avicennia sp.) Sebagai Bahan Pangan dan Obat-obatan, IPB Press, Bogor, 2009.

[4] E. Odum (Ed.), Dasar-Dasar Ekologi, UGM Press, Yogyakarta, 1993.

[5] M. F. Fachrul (Ed.), Metode Sampling Bioekologi, Bumi Aksara, Jakarta, 2007. 
[6] L. E. Harris, L. C. Kearl, P. V. Fonnesbeck, "Use of regression equations in predicting availability of energy and protein," Journal of Animal Science, vol. 35, no. 3, pp. 658-680. 1972.

[7] National Research Council (Ed.), Nutrient Requirement of Beef Cattle, National Academy Press, Washington DC, 1984.

[8] Ditjen Peternakan dan Fakultas Peternakan UGM, Investasi Limbah Pertanian Kerjasama Ditjen Peternakan dan Fakultas Peternakan UGM, UGM Press, Yogyakarta, 1982.

[9] M. Mukhtar, "Produksi dan daya dukung lahan hijauan pakan sapi potong di Kabupaten Gorontalo Utara," Jurnal Ilmiah Agrosains Tropis, vol. 7, no. 3, pp. 130-138. 2014.

[10] Kemdikbud (Ed.), Dasar-dasar Pemeliharaan Ternak, Balai Pustaka, Jakarta, 2013.

[11] E. Suhaema, Widiatmaka, B. Tjahjono, "Pengembangan wilayah peternakan sapi potong berbasis kualitas fisik lingkungan dan kesesuaian lahan untuk pakan di Kabupaten Cianjur," Jurnal Tanah Lingkungan, vol. 16, no. 2, pp. 53-60. 2014.

[12] T. Rahman, "Studi perencanaan pengembangan kawasan ternak di Kabupaten Pamengkasan," Jurnal Ilmiah Rekayasa, vol. 11, no. 1, pp. 60-73. 2018.

[13] S. Y. Ningsih, Ekologi Kepiting Bakau (Scylla serrata) di Hutan Mangrove Kelurahan Belawan Sicanang, Kecamatan Medan Belawan, Provinsi Sumatera Utara, USU Press, Medan, 2016.

[14] H. Halidah, "Avicennia marina (Forssk.) jenis mangrove yang kaya manfaat," Buletin Eboni, vol. 11, no. 1, pp. 37-44. 2014. 